\title{
KURIKULUM PENDIDIKAN AGAMA ISLAM DI SEKOLAH UMUM
}

\section{Muhammad Hatim*}

\begin{abstract}
Abstrak: Diskursus kurikulum sampai saat ini masih hangat untuk diperbincangkan, sebab kurikulum mempunyai peranan yang sangat signifikan dalam dunia pendidikan, bahkan bisa dikatakan bahwa kurikulum memegang kedudukan dan kunci dalam pendidikan, hal ini berkaitan dengan penentuan arah, isi, dan proses pendidikan, yang pada akhirnya menentukan macam dan kualifikasi lulusan suatu lembaga pendidikan. Kurikulum pendidikan agama Islam di sekolah terdiri dari beberapa apek yaitu, aspek al-Qur'an Hadits, Keimanan atau Aqidah, Akhlak, Fiqh (Hukum Islam), dan aspek Tarikh (Sejarah). Pendidikan Islam pada dasarnya bertujuan untuk mengantarkan peserta didik agar memiliki kemantapan akidah dan kedalaman spritual, keunggulan akhlak. Tulisan ini melihat bagaimana implementasi kurikulum PAI di sekolah, keunggulan dan kelemahan kurikulum PAI di sekolah dan solusi-solusi permasalahan praktik PAI di Sekolah.
\end{abstract}

Kata Kunci: Kurikulum, Pendidikan Agama Islam, Sekolah

T urikulum adalah jantung dalam dunia pendidikan. Ibaratkan dalam organ tubuh manusia, ketika jantungnya - sehat maka tubuhnya pun terasa sehat dan apabila jantungnya sakit maka jantungnya pun akan memburuk kondisinya, dan apabila dalam keadaan tersebut dan terus dipaksakan untuk bekerja maka akan berdampak kepada badannya (tubuhnya), begitu juga dengan kurikulum.Kurikulum merupakan pedoman mendasar dalam proses belajar dan mengajar di dunia pendidikan. Berhasil tidaknya suatu pendidikan, mampu tidaknya seorang anak didik dan

* Penulis adalah Dosen DLB Jurusan PAI Fakultas Ilmu Tarbiyah dan Keguruan UIN Mataram email: hatimmaulana@gmail.com 
pendidik dalam menyerap dan memberikan pelajaran, sukses tidaknya suatu tujuan pendidikan itu dicapai tentu akan sangat bergantung kepada kurikulum. Bila kurikulumnya didesain dengan sistematis dan komprehensif serta integral dalam segala kebutuhan pengembangan dan pembelajaran anak didik untuk mempersiapkan diri menghadapi kehidupannya, tentu hasil atau output pendidikan itu pun akan mampu mewujudkan harapan (Idi 2010, 5). Diskursus kurikulum sampai saat ini masih hangat untuk diperbincangkan, sebab kurikulum mempunyai peranan yang sangat signifikan dalam dunia pendidikan, bahkan bisa dikatakan bahwa kurikulum memegang kedudukan dan kunci dalam pendidikan, hal ini berkaitan dengan penentuan arah, isi, dan proses pendidikan, yang pada akhirnya menentukan macam dan kualifikasi lulusan suatu lembaga pendidikan. Kurikulum menyangkut rencana dan pelaksanaan pendidikan baik dalam lingkup kelas, sekolah, daerah, wilayah maupun nasional (Sukmadinata 2000, v).

Kurikulum sebagai rancangan pendidikan mempunyai kedudukan yang cukup sentral dalam keseluruhan kegiatan pembelajaran, menentukan proses pelaksanaan dan hasil pendidikan. Mengingat pentingnya peran kurikulum dalam pendidikan dan dalam perkembangan kehidupan peserta didik nantinya, maka pengembangan kurikulum tidak bisa dikerjakan sembarangan,harus berorentasi kepada tujuan yang jelas sehingga akan menghasilkan hasil yang baik dan sempurna (Amri, dan Ahmadi 2010, 61-62). Undang-undang Nomor 20 tahun 2003 tentang sistem pendidikan nasional dinyatakan bahwa kurikulum adalah seperangkat rencana dan pengaturan mengenai tujuan, isi, dan bahan pelajaran serta cara yang digunakan sebagai pedoman penyelenggaraan kegiatan pembelajaran untuk mencapai tujuan pendidikan tertentu (UU Sisdiknas No. 20 Tahun 2003, 5). Sehingga kurikulum merupakan salah satu komponen pokok aktivitas pendidikan, dan merupakan penjabaran idealisme, cita-cita, tuntutan masyarakat, atau kebutuhan tertentu. Dari kurikulum inilah akan diketahui arah pendidikan, alternatif pendidikan, fungsi pendidikan, serta hasil pendidikan yang hendak dicapai dari 
aktivitas pendidikan. Kurikulum PAI merupakan seperangkat rencana kegiatan dan pengaturan mengenai isi dan bahan pelajaran PAI serta cara yang digunakan dan segenap kegiatan yang dilakukan oleh guru agama untuk membantu seorang atau sekelompok siswa dalam memahami, menghayati, dan mengamalkan ajaran Islam atau menumbuhkembangkan nilai-nilai Islam. Termasuk juga didalamnya segenap fenomena atau peristiwa perjumpaan antara dua orang atau lebih yang berdampak pada tertanamnya ajaran Islam dan atau tumbuh kembangnya nilai-nilai Islam pada salah satu atau beberapa pihak, pada yang terakhir ini biasanya terwujud dalam bentuk penciptaan suasana religius di sekolah (Muhaimin 2004, 104).

Kurikulum PAI di sekolah umum terdiri atas beberapa aspek, yaitu aspek Al-Qur'an Hadits, Keimanan atau Aqidah, Akhlak, Fiqih (Hukum Islam), dan aspek Tarikh (Sejarah). Pendidikan Islam pada dasarnya hendak mengantarkan peserta didik agar memiliki kemantapan akidah dan kedalaman spiritual, keunggulan akhlak, wawasan pengembangan dan keluasan iptek, dan kematangan profesional.Secara normatif Pendidikan Islam (PAI) di sekolah umum sebagai refleksi pemikiran pendidikan Islam, sosialisasi, internalisasi, dan rekontruksi pemahaman ajaran dan nilai-nilai Islam. Secara praktis PAI bertujuan mengembangkan kepribadian muslim yang memiliki kemampuan kognitif, afektif, normatif, dan psikomotorik, yang kemudian diejawantahkandalam cara berfikir, bersikap, dan bertindak dalam kehidupannya (Hamami 2006, 1). Sehingga diharapkan dengan pembelajaran PAI dapat menjadikan peserta didik mampu mengembangkan kepribadian sebagai muslim yang baik, menghayati dan mengamalkan ajaran serta nilai Islam dalam kehidupannya. Dan kemudian PAI tidak hanya dipahami secara teoritis, namun dapat diamalkan secara praktis. Pendidikan Agama Islam di sekolah pada dasarnya lebih diorientasikan pada tataran moral action, yakni agar peserta didik tidak hanya berhenti pada tataran kompetensi (competence), tetapi sampai memiliki kemauan (will), dan kebiasaan (habit) dalam mewujudkan ajaran dan nilai-nilai agama tersebut dalam kehidupan sehari-hari (Muhaimin 2009, 313). 


\section{Pengertian Kurikulum}

Sebelum mengkaji lebih jauh tentang kurikulum PAI, perlu dikemukakan terlebih dahulu apa itu kurikulum. Kata "Kurikulum"berasal dari kata Yunani yang semula digunakan dalam bidang olah raga, yaitu currere yang berarti jarak tempuh lari, yakni jarak yang harus ditempuh dalam kegiatan berlari mulai dari star hingga finish. Jarak dari star sampai finish ini kemudian yang disebut dengan currere (Ahmad, dkk. 1998, 9). Berdasarkan pengertian ini, dalam konteksnya dengan dunia pendidikan, memberi pengertian sebagai "Circle of Instruction" yaitu suatu lingkaran Pengajaran di mana guru dan murid terlibat di dalamnya.Dalam bahasa Arab, istilah "kurikulum" diartikan dengan Manhaj, yakni jalan yang terang, atau jalan yang terang yang dilalui oleh manusia pada bidang kehidupannya (Ahmad, dkk. 1998, 9).

Dalam konteks pendidikan, kurikulum berarti jalan terang yang dilalui oleh pendidik atau guru dengan peserta didik untuk mengembangkan pengetahuan, keterampilan dan sikap serta nilainilai (al-Syaibani 1979, 478). Sementara itu menurut E. Mulyasa bahwa kurikulum adalah seperangkat rencana dan pengaturan mengenai tujuan, kompetensi dasar, materi standar, dan hasil belajar, serta cara yang digunakan sebagai pedoman penyelenggaraan kegiatan pembelajaran untuk mencapai hasil kompetensi dasar dan tujuan pendidikan (Muhaimin 2005, 1).

Konsep kurikulum meliputi semua pengalaman, aktivitasaktivitas suasana dan pengaruh-pengaruh yang diberikan kepada murid-murid atau mereka mengerjakan atau mereka jumpai dalam sekolah dan di bawah kelolaan sekolah. Sebab semuanya itu memberi pengaruh pada tingkah laku mereka dan memberi sumbangan dalam perkembangan yang menyeluruh dan lengkapmelengkapi. Mengikut pengertian yang baru tentang kurikulum ini, kurikulum itu bukan hanya meliputi mata pelajaran dan pengalaman-pengalaman yang tersusun yang berlaku dalam kelas, tetapi meliputi juga semua kegiatan kebudayaan, kesenian, olahraga, dan sosial yang dikerjakan oleh murid-murid di luar jadwal waktu 
dan di luar kelas dalam dan di bawah kelolaan sekolah (al-Syaibani 1979, 484).

Jadi menurut Dr. Addamardasi Sarhan dan Dr. Munir Kamil sebagaiamana dikutip oleh Omar Mohammad al-Toumy alSyaibani dalam bukunya mendefinisikan kurikulum sebagai "sejumlah pengalaman-pengalaman pendidikan, budaya, sosial, olahraga, dan seni, yang disediakan oleh sekolah bagi muridmuridnya di dalam dan di luar sekolah dengan maksud menolongnya untuk berkembang menyeluruh dalam segala segi dan merubah tingkah laku mereka sesuai dengan tujuan-tujuan pendidikan" (al-Syaibani 1979, 484).

\section{Dasar Kurikulum Pendidikan Agama Islam}

Kurikulum sebagai salah satu komponen pendidikan yang sangat berperan dalam mengantarkan pada tujuan pendidikan yang diharapkan, harus mempunyai dasar-dasar yang merupakan kekuatan utama yang mempengaruhi dan membentuk materi kurikulum, susunan dan organisasi kurikulum.

Menurut Al-Syaibani menawarkan dasar-dasar kurikulum sebagai berikut :

a) Dasar Agama, tujuan dan kurikulumnya pada dasar agama Islam dengan segala aspeknya. Dasar agama ini dalam kurikulum pendidikan Islam jelas harus berdasarkan pada alQur'an, al-Sunnah dan sumber-sumber yang bersifat furu' lainnya.

b) Dasar Falsafah, dasar ini memberikan pedoman bagi tujuan pendidikan Islam secara filosofis, sehingga tujuan, isi dan organisasi kurikulum mengandung suatu kebenaran dan pandangan hidup dalam bentuk nilai-nilai yang diyakini sebagai suatu kebenaran, baik ditinjau dari sisi ontology, epistemologi, maupun aksiologi.

c) Dasar Psikologi, dasar ini memberikan landasan dan perumusan bahwa dalam perumusan kurikulum yang sejalan dengan ciri-ciri perkembangan psikis peserta didik, sesuai dengan tahap kematangan dan bakatnya. 
d) Dasar Sosial, dasar ini memberikan gambaran bagi kurikulum pendidikan Islam yang tercermin pada dasar sosial yang mengandung ciri-ciri masyarakat Islam dan kebudayaannya. Baik dari segi pengetahuan, nilai-nilai ideal, cara berfikir dan adat kebiasaan, seni dan sebagainya. Kaitannya dengan kurikulum pendidikan Islam sudah tentu kurikulum ini harus mengakar terhadap masyarakat dan perubahan dan perkembangannya (al-Syaibani 1979, 484).

Sementara itu Herman H. Horne memberikan dasar bagi penyusunan kurikulum dengan tiga macam, yaitu :

1. Dasar Psikologis, yang digunakan untuk memenuhi dan mengetahui kemampuan yang diperoleh dari pelajar dan kebutuhan anak didik (the ability and needs of children).

2. Dasar Sosiologis, yang digunakan untuk mengetahui tuntunan yang sah dari masyarakat (the legitimate demands of society)

3. Dasar Filosofis, yang digunakan untuk mengetahui keadaan alam semesta tempat kita hidup (the kind of universe in which we live). (Ramayulis 2004, 131)

\section{Implementasi Kurikulum PAI di sekolah umum}

Penerapan kurikulum Pendidikan Agama Islam, memiliki sifat kebergantungan yang sangat tinggi, ia sangat dipengaruhi oleh fasilitas serta potensi yang tersedia di sekolah, lingkungan, masyarakat, serta lingkungan pergaulan para siswa, latar belakang keluarga, dipengaruhi pula oleh bagaimana persepsi guru yang bersangkutan terhadap kurikulum (Majid, dkk. 2005, 176). Dalam kerangka penerapan kurikulum PAI pada sekolah umum, para guru agama diperlukan mampu membaca "visi" sebuah kurikulum, yakni ide-ide pokok yang terkandung di dalam tujuan-tujuan kurikulum. Ide pokok tersebut dibentuk dari filsafat, teori serta kebijakankebijakan formal yang melandasinya. Di samping kemampuan mereka dalam menganalisis struktur kurikulumnya, guru juga harus mampu membaca visi kurikulum PAI, terutama agar persepsi yang dibentuk dalam pemikiran guru agama itu terdapat relevansi dengan 
visi kurikulum yang secara prinsip terkandung dalam tujuan-tujuan kurikulumnya.

Pemahaman yang relevan terhadap kurikulum mata pelajaran PAI, penting sekali bagi para guru Agama Islam, sebab selanjutnya akan dijadikan pedoman bagi mereka, dalam sistem pengembangan atau penerapan kurikulumnya secara sistemik dan sistematis. Pendidikan Agama Islam diharapakan dapat menghasilkan manusia yang selalu berupaya menyempurnakan iman, taqwa dan akhlak,serta aktif membangun peradaban keharmonisan kehidupan, khususnya dalam memajukan peradaban bangsa yang bermartabat.

Pembelajaran Pendidikan Agama Islam merupakan bentuk nyata pelaksanaan Kurikulum PAI dalam kelas yang melibatkan unsur-unsur personal kepala sekolah dan guru, siswa, sumber belajar serta sarana dan prasarana keberhasilan suatu pelaksanaan.

Proses pembelajaran Kurikulum Pendidikan Agama Islam sebagai rencana yang memiliki komponen-komponen yang teridiri dari: tujuan,materi pelajaran,prosesatau metode serta penilaian.

Adapun fakor-faktor pendukung implementasi kurikulum PAI sebagai berikut :

\section{Faktor Guru}

Guru merupakan salah satu unsur kependidikan yang berperan aktif dan menempatkan kedudukannya sebagai tenaga professional, sesuai dengan tutunan masyarakat yang semakin berkembang. Karena itu guru tidak semata-mata sebagai transfer of values, melainkan juga sebagai pembimbing yang memberikan pengarahan dan menuntun siswa dalam belajar. Faktor guru cukup berperan dalam implementasi kurikulum dan berakibat lansung pada perubahan sekolah sebagai suatu sistem sosial.

Guru adalah salah satu faktor yang mempengaruhi kualitas pendidikan. Para pakar menyatakan bahwa, betapa bagusnya sebuah kurikulum hasilnya sangat bergantung pada apa yang dilakukan guru di dalam ataupun diluar kelas. Kualitas pembelajaran yang sesuai dengan rambu-rambu PAI dipengaruhi pula oleh sikap guru yang kreatif untuk melilih dan melaksanakan 
berbagai pendekatan dan model pembelajaran. Karena profesi guru menuntut sifat kreatif dan kemauan mengadakan improvisasi.Oleh karena itu guru harus menumbuhkan dan mengembangkan sikap kreatifnya dalam mengelola pembelajaran dengan memilih dan menetapkan berbagai pendekatan, metode, media pembelajaran yang relevan dengan kondisi siswa dan pencapaian kompetensi, karena guru harus menyadari secara pasti belumlah ditemukan suatu pendekatan tunggal yang berhasil menangani semua siswa untuk mecapai berbagai tujuan.

Keberhasilan Pendidikan Agama Islam dapat dipengaruhi juga oleh beberapa faktor. Sebagaiamana dikutip oleh Abdul Majid dalam bukunya J. Mars Curriculum Proces in the Primary Schoolmengemukakan bahwa ada 5 unsur yang dapat mempengaruhi terhadap keberhasilan pembelajaran disekolah, yaitu:

(a) Dukungan dari kepala sekolah

(b) Dukungan dari teman sejawat atau sesama guru

(c) Dukungan dari siswa sebagai peserta didik

(d) Dukungan dari orang tua atau masyarakat

(e) Dukungan atau dorongan guru sebagai pendidik

Dari kelima unsur di atas yang paling menentukan berhasil tidaknya suatu proses pembelajaran adalah faktor guru. Posisi dan peran guru dalam pendidikan merupakan ujung tombak dalam menentukan berhasil tidaknya suatu rancangan program pembelajaran.

Guru dalam proses pembelajaran memegang peran yang sangat penting. Dalam proses pembelajaran guru bukanlah hanya berperan sebagai model atau teladan bagi siswa yang diajarnya, akan tetapi juga sebagai pengelola pembelajaran (manager of learning)dengan demikian, efektivitas proses pembelajaran terletak di pundak guru. Oleh karenanya keberhasilan suatu proses pembelajaran ditentukan oleh kualitas atau kemampuan guru (Majid, dkk. 2005, 166).

Menurut Dunkin, ada sejumlah aspek yang dapat mempengaruhi kualitas proses pembelajaran di lihat dari faktor guru yaitu: 
1) Teacher formatif experience, meliputi jenis kelamin serta semua pengalaman hidup guru yang menjadi latar belakang sosial mereka meliputi tempat asal kelahiran guru,suku,latar belakang budaya dan adat istiadat,keadaan keluarga dimana guru itu berasal,apakah berasal dari kelurga yang tergolong mampu atau tidak.

2) Teacher training experience, meliputi pengalaman-pengalaman yang berhubungan dengan aktivitas dan latar belakang pendidikan guru, misalnya pengalaman latihan professional,tingkatan pendidikan pengalaman jabatan dan lain sebagainya.

3) Teacher properties,adalah segala sesuatu yang berhubungan dengan sifat yang dimiliki guru. Misalnya sikap guru terhadap profesinya,sikap guru terhadap siswa,kemampuan atau intelegensi guru, motivasi dan kemampuan dalam pengelolaan dalam pembelajaran termasuk di dalamnya kemampuan dalam merencanakan dan evalusi pembelajaran maupun kemampuan dalam penguasaan materi pelajaran. (Majid, dkk. 2005, 166)

\section{Faktor Siswa}

Siswa adalah organisme yang unik yang berkembang sesuai dengan tahap perkembangannya. Perkembangan anak adalah seluruh aspek kepribadiannya, akan tetapi tempo dan irama perkembangan masing-masing anak pada setiap aspek tidak selalu sama.Seperti halnya guru, faktor-faktor yang dapat mempengaruhi proses pembelajaran dilihat aspek siswa meliputi aspek latar belakang siswa (pupil formative experience) serta faktor sifat yang dimilki siswa (pupil properties).

Aspek latar belakang meliputi jenis kelamin, tempat kelahiran dan tempat tinggal siswa, tingkat sosial ekonomi siswa, dari keluarga yang bagaimana siswa berasal dan lain sebagainya. Sedangkan dilihat dari sifat yang dimiliki siswa meliputi kemampuan dasar,pengetahun dan sikap.Sikap dan penampilan siswa didalam kelas, juga merupakan aspek lain yang dapat mempengaruhi proses pembelajaran. Adakalanya ditemukan siswa 
yang sangat aktif (byperkinetik) dan ada pula siswa yang pendiam, tidak sedikit juga siswa dikemukan siswa yang memilki motivasi yang rendah dalam belajar. Semua itu akan mempengaruhi proses pembelajaran di dalam kelas. Sebab, bagaimanapun faktor siswa dan guru merupakan faktor yang sangat menentukan dalam interaksi pembelajaran (Majid, dkk. 2005, 166).

\section{Faktor Sarana dan Prasana}

Hasil penelitian menunjukkan bahwa penerapan Pendidikan Agama Islam memiliki ketergantungan yang sangat tinggi, ia dipenggaruhi oleh fasilitas, kondisi sekolah, keluarga, siswa serta bagaimana persepsi guru terhadap kurikulum.Departemen Agama mengemukakan ciri-ciri siswa dan permasalahan yang dihadapinya pada sekolah umum, kemampuan siswa beterogen, waktu jam pelajaran yang terbatas, minat siswa besar pada mata pelajaran lain, dan sarana PAI yang terbatas.

Sarana adalah segala sesuatu yang mendukung secara langsung terhadap kelancaran proses pembelajaran, misalnya media pembelajaran, alat pembelajaran, perlengkapan sekolah dan lain sebagainya. Sedangkan prasana adalah sesuatu secara tidak langsung dapat mendukung keberhasilan proses pembelajaran misalnya, jalan menuju sekolah, penerangan sekolah, kamar kecil dan lain sebagainya.Kelengkapan sarana dan prasana akan membantu guru dalam penyelenggaraan proses pembelajaran, dengan demikian sarana dan prasana merupakan komponen penting yang dapat mempengaruhi proses pembelajaran. Beberapa keuntungan bagi sekolah yang memilki kelengkapan sarana dan prasana, yaitu:

a) kelengkapan dapat menumbuhkan gairah dan motivasi guru mengajar.

b) kelengkapan sarana dan prasana dapat memberikan berbagai pilihan pada siswa untuk belajar. (Majid, dkk. 2005, 166)

\section{Faktor Lingkungan}

Dilihat dari dimensi lingkungan ada dua faktor yang dapat mempengaruhi proses pembelajaran, yaitu faktor organisasi kelas dan dan faktor iklim sosial-psikolgis. Faktor organisasi kelas yang di 
dalamnya meliputi jumlah siswa dalam satu kelas merupakan aspek penting yang dapat mempengaruhi proses pembelajaran. Organisasi kelas yang terlalu besar akan kurang efektif untuk mencapai tujuan pembelajaran.

Iklim sosial-psikologis secara internal adalah hubungan antara orang yang terlibat dalam lingkungan sekolah, misalnya iklim sosial antara siswa dengan siswa; antara siswa dengan guru; antara guru dan guru bahkan guru dengan pimpinan sekolah. Iklim-piskologis eksternal adalah keharmonisan hubungan antara pihak sekolah dengan dunia luar; misalnya sekolah dengan orang tua siswa,hubungan sekolah dengan lembaga-lembaga masyarakat dan lain sebagainya.

Pendidikan Agama Islam merupakan pendidikan yang menanamkan nilai-nilai fundamental Islam, dimana setiap muslim terlepas dari disiplin ilmu apapun yang akan dikaji. Namun, persoalan yang kemudian muncul adalah pratek dan realita sosial yang terjadi di Indonesia, sering kali menjadi tolok ukur berhasil atau tidaknya suatu pendidikan agama Islam disekolah. Buruknya kehidupan sosial di Indonesia ditandai dengan praktek hidup korup, tingginya penggunaan narkoba serta kehidupan yang materialistik menjadikan pendidikan agama Islam disekolah sebagai pihak yang memikul tanggung jawab.

Oleh karena itu perlu adanya revitalisasi pendidikan agama Islam yang melibatkan semua pihak yang terkait baik orang tua, guru, maupun masyarakat, perlu mengkaji proses dan struktur terbentuk aspek afektif dalam prosespembelajaran agama Islam.Adapun upaya-upaya yang dapat dilakukan dalam rangka revitalisasi pendidikan agama Islam antara lain:

a. Melakukan penilaian pencapaian belajar yang berorientasi pada aspek afektif tidak hanya terpusat pada kognitifnya saja.

b. Mengubah cara pandang terhadap kurikulum pendidikan agama Islam.

c. Adanya pendekatan yang bersifat values clarification dalam pembelajan pendidikan agama Islam. 
d. Mengubah strategi pembelajaran dari model pembelajaran tradisional menjadi model pembelajaran yang inovatif serta menyenangkan

e. Adanya kerja sama antara guru, kepala sekolah, masyarakat dan keluarga dalam memperhatikan perkembangan sikap anak.

f. Tersedianya sarana dan prasarana yang lengkap di sekolah

Dengan demikian dalam tataran praksis bahwa kurikulum sebagai hasil belajar dan sebagai pembelajaran. Pembelajaran agama Islam bukan sekedar kurikulum tertulis yang hanya disampaikan sebagai pengetahuan (kognitif) saja. Tetapi kurikulum PAI mampu memberikan nilai terhadap peserta didik dengan pemahaman, perilaku, sikap terhadap materi yang ada (Majid, dkk. 2005, 166).

Di dalam GBPP mata pelajaran pendidikan Agama Islam kurikulum 1994 pada dasarnya mencakup tujuh unsur pokok yaitu, al-Qur'an dan al-Hadits, Keimanan atau Aqidah, Akhlak, Fiqh (hukum Islam), dan Tarikh (sejarah) yang menekankan pada perkembangan politik. Pada kurikulum tahun 1999 dipadatkan menjadi lima unsur pokok, yaitu al-Qur'an, Aqidah, Akhlak, Fiqh, dan bimbingan ibadah serta Tarikh atau sejarah yang lebih menekankan pada perkembangan ajaran agama, ilmu pengetahuan dan kebudayaan (Muhaimin 2005, 259). Meskipun masing-masing aspek tersebut dalam praktiknya saling terkait (mengisi dan melengkapi), tetapi jika dilihat secara teoritis masing-masing memiliki karakteristik sendiri.Aspek al-Qur'an-Hadis, menekankan pada kemampuan baca tulis yang benar, memahami makna secara tekstual dan kontekstual, serta mengamalkan kandungannya dalam kehidupan sehari-hari. Aspek Aqidah, menekankan pada kemampuan memahami dan mempertahankan keyakinan atau keimanan yang benar serta menghayati dan mengamalkan nilai-nilai al-asma' al-Husna. Aspek Akhlak, menekankan pada pembiasaan untuk melaksanakan akhlak terpuji dan menjauhi akhlak tercela dalam kehidupan sehari-hari. Aspek Fiqh, menekankan pada kemampuan cara melaksanakan ibadah dan muamalah yang benar dan baik. Sedangkan aspek Tarikh dan kebudayaan Islam, 
menekankan pada kemampuan mengambil ibrah dari peristiwaperistiwa bersejarah (Islam), meneladani tokoh-tokoh berprestasi dan mengaitkannya dengan fenomena sosial, budaya, politik, iptek, dan lain-lain untuk mengembangkan kebudayaan dan peradaban Islam.

Pendidikan Agama Islam di sekolah pada dasarnya lebih dioientasikan pada tataran moral action yakni agar peserta didik tidak hanya berhenti pada tataran kompeten tetapi memiliki kemauan dan kebiasaan dalam mewujudkan ajaran dan nilai-nilai agama tersebut dalam kehidupan sehari-hari (Muhaimin 2005, 259). Pendidikan agama Islam di sekolah umum terselenggara sebagai upaya pengintegrasian pendidikan Islam ke dalam sistem sekolah yang kurikulumnya berorientasi pada pengetahuan umum. Perubahan yang perlu dilakukan dalam sistem pendidikan Islam memasukkan pendidikan agama ke dalam pendidikan umum. Hal ini merupakan langkah penyesuaian bagi tercapainya fungsi pendidikan dalam memenuhi tuntutan perkembangan masyarakat modern.

\section{Keberhasilan dan KelemahanKurikulum Pendidikan Agama Islam di sekolah umum}

Penilaian secara moderat, pendidikan agama Islam di sekolah umum berhasil, tetapi dalam beberapa hal masih mengalami hambatan dan rintangan. Diantara keberhasilannya itu; pertama, dengan dilakukan program pendidikan agama Islam di sekolah umum, dilihat dari perspektif cita-cita pendidikan nasional, usaha Departemen Agama dalam membina pendidikan agama di sekolah umum telah berhasil mewujudkan cita-cita konvergensi. Para siswa sekolah umum mengenal dan mempelajari agama di sekolahnya masing-masing selain pelajaran-pelajaran umum. Kedua, sekolah sepenuhnya tidak bersifat sekuler, karena peserta didik belajar agama dan mengamalkannya. Ketiga, di sisi lain, madrasah dan sekolah-sekolah agama tidak lagi menganggap ilmu-ilmu umum hal yang bersifat dunia yang diharamkan untuk dipelajari, sekarang 
ilmu-ilmu umum dipelajari oleh siswa-siswa madrasah dan sekolah agama (Muhaimin 2005, xxxiii).

Lembaga-lembaga pendidikan Islam sebagai penyelenggara pendidikan agama memiliki peluang dan sekaligus tantangan berkenaan jenis pendidikan yang dapat dipilih dan diselenggarakan, setidaknya ada empat pilihan; pertama, Pendidikan yang berpusat pada tafaqqub fi al-din, seperti yang ada dalam tradisi pesantren pada masa pra-modernisasi (pesantren salafiyah), dengan muatan kurikulum yang hampir sepenuhnya ilmu agama. Kedua, Pendidikan madrasah yang mengikuti kurikulum Diknas dan Depag. Madrasah semula merupakan "pendidikan agama plus umum", tetapi sesuai UUSPN 1989 madrasah adalah "sekolah umum berciri agama". Ketiga, Sekolah Islam "plus" atau "unggulan" yang mengikuti kurikulum Diknas, yang pada dasarnya adalah "pendidikan umum plus agama". Keempat, Pendidikan ketrampilan (vocational training), apakah mengikuti model "STM" atau MA/SMU ketrampilan. Keempat pilihan tersebut, menjawab sejumlah harapan masyarakat kepada pendidikan Islam di era globalisasi. Harapan pertama, Pendidikan Islam berperan dalam dua hal pokok; pertama, transmisi ilmu-ilmu dan pengetahuan Islam (transmission of Islamic knowledge). Kedua, pemeliharaan tradisi Islam (maintenance of Islamic tradition). Ketiga, reproduksi (calon-calon) ulama (reproduction of "ulama"). Harapan kedua, agar para peserta didik tidak hanya mengetahui ilmu agama, tetapi juga ilmu umum atau sebaliknya sehingga diharapkan terjadi mobilitas pendidikan. Harapan ketiga, agar para anak didik memiliki ketrampilan, keahlian atau life skills khususnya dalam bidang sains dan teknologi yang menjadi karakter dan ciri masa globalisasi (Azra 2009, 19).

Untuk mengukur keberhasilan siswa setelah mempelajari pelajaranPendidikan Agama Islam (PAI), siswa diharapkan memiliki sembilan indikator,yaitu:

1. Siswa memiliki pengetahuan fungsional tentang agama Islam dan mengamalkannya.

2. Siswa meyakini kebenaran ajaran agama Islam dan menghormati orang lain meyakini agamanya pula. 
3. Siswa bergairah dalam beribadah.

4. Siswa terbiasa membaca kitab suci al-Qur'an dan berusahamemahaminya.

5. Siswa memiliki sifat kepribadian muslim (berakhlak mulia).

6. Siswa rajin belajar, giat belajar dan gemar berbuat baik.

7. Siswa mampu mensyukuri nikmat Allah SWT.

8. Siswa memahami, menghayati dan mengambil manfaat dari tarikh Islam.

9. Siswa mampu menciptakan suasana kerukunan hidup beragama dalam kehidupan bermasyarakat, berbangsa dan bernegara. (Departemen Agama RI 2003, 5-8)

Mochtar Buchori menilai pendidikan agama masih gagal. Kegagalan ini disebabkan karena praktik pendidikannya hanya memperhatikan aspek kognitif semata dari pertumbuhan kesadaran nilai-nilai (agama), dan mengabaikan pembinaan aspek afektif dan konotif-volitif, yakni kemauan dan tekad untuk mengamalkan nilainilai ajaran agama. Akibatnya terjadi kesenjangan antara pengetahuan dan pengamalan, antara gnosis dan praxis dalam kehidupan nilai agama. Atau dalam praktik pendidikan agama berubah menjadi pengajaran agama, sehingga tidak mampu membentuk pribadi-pribadi bermoral, padahal intisari dari pendidikan agama adalah pendidikan moral.

Muhaimim menuliskan indikator-indikator kelemahan pelaksanaan PAI di sekolah-sekolah;

a) PAI kurang bisa mengubah pengetahuan Agama yang kognitif menjadi makna dan nilai atau kurang mendorong penjiwaan terhadap nilai-nilai keagamaan yang perlu diinternalisasikan dalam diri peserta didik.

b) PAI kurang dapat berjalan bersama dan bekerja sama dengan program-program pendidikan non-agama.

c) PAI kurang mempunyai relevansi terhadapperubahan sosial budaya atau bersifat statis kontekstual dan lepas dari sejarah, sehingga Peserta didik kurang menghayati nilai-nilai agama sebagai nilai yang hidup dalam keseharian. (Muhaimin 2006, 37) 
Ahmad Tafsir (2013, 184) menyebutkan 12 kelemahan PAI di sekolah:

a. Kurangnya dukungan orang tua murid

b. PAI kurang diminati

c. Kurikulum PAI terlalu luas

d. Pelajaran agama kurang berguna bagi kehidupan material

e. Tidak di UN kan

f. Kurang Peneladanan dari guru

g. Kurangnya Pembiasaan dari sekolah

h. Penampilan guru agama kurang menarik

i. Budaya Global

j. Spiritualisme melawan Materialisme

k. PAI tidak menyatu dalam sistem

1. PAI tidak menjadi fokus dalam kehidupan sehari-hari.

Berbagai kritik atas atas kelemahan dari pelaksanaan pendidikan agama lebih banyak bermuara pada aspek metodologi pembelajaran PAI dan orientasinya yang lebih bersifat normatif, teoritis dan kognitif, serta kurang mempunyai relevansi terhadapPerubahan sosial yang terjadi di masyarakat atau kurang ilustrasi konteks sosial budaya dan bersifat statis tidak kontekstual serta lepas dari sejarah, sehingga peserta didik kurang menghayati nilai-nilai agama sebagai nilai yang hidup dalam keseharian dan lain-lain. Aspek yang disoroti adalah menyangkut muatan kurilum atau materi pendidikan agama , sarana pendidikan agama, termasuk di dalamnya buku-buku dan bahan-bahan ajar pendidikan agama (Tafsir 2013, 184).

\section{Solusi-solusi Permasalahan Praktik Pendidikan Agama Islam di Sekolah}

Persoalan sebenarnya bukanlah terletak pada persoalan mata pelajaran apa yang lebih mungkin mampu membentuk prilaku atau pribadi siswa secara efektif. Pendidikan budi pekerti sekalipun, andaikata diajarakan secara kognitif akan melahirkan problem yang sama. Pendidikan agama dan pendidikan budi pekerti bukanlah dua hal yang harus dipertentangkan, melainkan bersifat saling komplementer. Dalam hal ini, penyempurnaan sistem pendidikan 
agama terutama dalam orientasi dan penekanan aspek kompetensi yang harus di ajarkan menjadi hal yang sangat penting. Materi pendidikan agama, harus diorientasikan kepada pengusaan, pemahaman, penghayatan, dan pengamalan nilai dan norma ajaran agama secara komperhensif sehingga kelak mampu membentuk kepribadian yang utuh. Pendidikan agama harus disajikan dengan pendekatan yang tepat sesuai ideologi pembangunan yang telah dirumuskan pemerintah dan tuntutan pembentukan kepribadian peserta didik sesuai perkembangan tantangan zamannya. Kesalahan pendekatan pendidikan agama, ternyata tidak hanya menyebabkan "prestasi sekolah yang rendah, namun dapat menyebabkan pula terbentuknya perilaku yang tidak diharapkan (Mudzhar 2010, 108). Salah satu masalah yang dihadapi pengajaran agama Islam di sekolah adalah adanya kekurangan jam pelajaran agama Islam yang disediakan di sekolah-sekolah.

Dengan demikian diperlukan pendekatan pembelajaran PAI yang dapat menumbuhkan karakter siswa, Pada dasarnya karakter ini lebih bermuatan aspek afektif. Dengan mengacu taksonomi pembelajaran menurut Benyamin. S. Bloom cakupan domain afektif terdiri dari ;
a. Penerimaan ( Receiving )
b. Sambutan (Responding)
c. Penilaian (Valuing )
d. Pengorganisasian (Organization )
e. Karakterisasi (Characterazation )

Dengan Kerangka Pikir ini, Abudin Nata menawarkan pendekatan pembelajaran PAI dalam rangka menumbuhkan kembangkan potensi bagi siswa (Nata 2003, 31).

1. Modeling-Imitating: pendekatan pembelajaran PAI dengan menghadirkan perilaku yang baik dipraktikkan di lingkungan sekolah, kepala sekolah, guru, orang tua sebagai contoh dan model dimana siswa dapat melihat, mengamati, mempratikkan perilaku yang baik bagi mereka. Dengan pemberian contoh yang baik, Uswatun Hasanah atau Qudwah Hasanah, menguatkan materi yang dipelajari siswa di kelas. 
Materi PAI tidak sebatas materi belaka yang sifatnya abstrak, tetapi siswa mendapat pembuktian secara praktik langsung dalam kehidupan sehari-hari. Dengan apa yang dilihatnya dari orang-orang di sekitarnya semakin memberi keinginan untuk mempratikkan materi-materi yang telah dipelajarinya.

2. Reflecting: Pendekatan yang bertujuan, siswa mampu mendapatkan sebuah pantulan atau masukan dengan apa yang telah dipelajarinya. Materi yang dipelajari tidak begitu saja lewat dilupakan tanpa meninggalkan bekas apa-apa yang bermanfaat setelah itu. Berefleksi berarti mencoba menilai perbuatan diri sendiri. Apakah proses pembelajaran yang dilakukannya sudah memberi suatu hal positif bagi dirinya. Dalam refleksinya, ternyata materi-materi PAI yang telah dipelajarinya, mengandung nilai-nilai universal, komprehensif, serta aplikatif yang berguna bagi kesuksesan hidupnya di dunia maupun di akhirat.

3. Problem Solving:pendekatan dengan melibatkan siswa dari setiappembelajaran PAI. Guru tidak lagi sebagai satusatunya sumber ilmu terhadap sebuah masalah. Objek materi yang dipelajari sebagai sebuah masalah yang harus dipecahkan dan dicarikan solusi. Dari sini timbul pemahaman terhadap sebuah masalah, masing-masing siswa akan memiliki pendapat yang berbeda dan bermacammacam. Keikut partisipasian semua siswa dalam memecahkan sebuah masalah, kemudian dirumuskan jalan solusinya, secara tidak langsung menuntut tanggung jawab atas semua hal yang telah mereka lalui.

4. Deep Discussion: pendekatan pembelajaran PAI yang menuntun masing-masing siswa berdiskusi secara mendalam, analisis, kritis terhadappemahaman ajaran Islam. Dari sini, Islam sebagai sebuah horizon ilmu pengetahuan yang ilmiah dan komprehensif. Pemahaman menggali kembali dari sumber ajaran al-Qur'an dan hadits, membaca pendapat para ulama, serta melihat hasil-hasil penemuan ilmiah terkini. Pemahaman siswa terhadap Islam yang 
dibangun, bereferensi yang otoritatif argumentasi yang rasional dan empirikal, serta memberi kemaslahatan bagi semesta.

5. Socialization:pendekatan pembelajaran PAI sebagai suatu proses implementasi yang dialami bagaimana sebuah ajaran atau nilai (PAI) bisa dipratikkan dalam kehidupan sehari-hari tanpa ada pertentangan. PAI sebagai sebuah materi penuh nilai, untuk bisa menjadi sebuah karakter yang dipratikkan dalam kehidupan sehari-hari, ada tahapan dan proses yang harus dilalui. Dimulai dari adaptasi, proses penyesuaian terhadap sesuatu hal yang baru (nilai PAI) dengan lingkungan sekitar, kemudian terjadi asimilasi yaitu saling pengaruh mempengaruhi antar yang sudah ada (lingkungan sekitar) dengan yang baru, kemudian terjadi kolaborasi, kedua unsur yang sudah ada dan baru bisa saling kerjasama sehingga selanjutnya terjadi Integrasi, yakni pembaruan yang masuk diantara kedua unsur (nilai PAI dan lingkungan sekitar) dengan lancar dan saling mengisi.

6. Autentik Assasment: pendekatan pembelajaran PAI dengan penilaian dan evaluasi yang terus menerus berkesinambungan dan berkelanjutan terhadap anak didiknya. Tindakan ini menuntut guru mampu melakukan penilaian secara observasi perilaku keseharian anak didiknya. Perilaku-perilaku keseharian siswa inilah sebagai informasi yang paling berharga dari pembelajaran PAI sendiri, terbiasanya siswa melakukan perbuatan-perbuatan yang mulia yang dituntut dari PAI. Selanjutnya, perilaku mulia ini menjadi karakter bagi siswa. Cara penilaian dapat dilakukan dengan portopolio ataupun diary book siswa.

Dalam pelaksanaan pendidikan Agama Islam di sekolah, banyak sekali muncul problematika-problematika. Berbagai problematika yang muncul, bisa berkenaan dengan masalah yang bersifat internal, maupun eksternal. Faktor Internal sekolah, misalnya guru yang belum berkompeten, maupun sarana-prasarana yang tidak mendukung.Sedangkan permasalahan dari eksternal, bisa datang 
dari kurangnya dukungan masayarakat (Orang Tua murid), ataupun kurangnya dukungan dari pemerintah daerah setempat.

Untuk mencapai kompetensi yang diharapkan dalam pembelajaran sesuai tujuan yang ditetapkan diperlukan pembelajaran yang efektif dan bermakna, sebab selama ini proses pembelajaran dirasakan belum memiliki makna yang berarti kepada peserta didik.Ada beberapa metode dan strategi pembelajaran yang bisa diterapkan dalam proses pembelajaran Agama Islam di sekolah atau madrasah di antaranya :

1. Student Centered Instruction, yaitu pembelajaran yang berpusat pada peserta didik, seperti diskusi dalam berbagai variasi, demonstrasi dan games. Dituntut peran aktif siswa, dan guru sebagai fasilitator

2. Collaborative Learning, yaitu pembelajaran aktif dimana siswa dan guru berkolaborasi atau dengan warga sekolah lainnya.

3. Cooperative learning, yaitu proses pembelajaran yang memberikan kesempatan kepada peserta didik terlibat langsung dalam pembelajaran secara berkelompok dalam mengerjakan tugas yang diberikan guru.

4. Self discovery learning, yaitu belajar melalui penemuan mereka sendiri, melalui observasi dan pengamatan terhadap masalah yang harus mereka pecahkan.

5. Quantum learning, yaitu strategi pembelajaran yang melibatkan seluruh komponen diri siswa, dengan pendekatan individu dan kelompok.

6. Contextual Teaching and Learning (CTL), yaitu strategi yang digunakan untuk untuk membantu peserta didik untuk memahami makna dan materi pelajaran dengan mengaitkan mata pelajaran tersebut dengan konteks kehidupan mereka.

Selain dengan pemilihan dan penggunaan strategi pembelajaran yang tepat Dalam pelaksanaan Pendidikan Agama Islam sebagai implementasi kurikulum PAI, ada beberapa hal terkait dengan implementasi tersebut.

Pertama, keteladanan, merupakan upaya konkrit dalam menanamkan nilai-nilai luhur pendidikan Agama Islam kepada 
peserta didik. Secara psikologis anak memang senang meniru; tidak saja yang baik, tetapi juga yang tidak baik. Perilaku yang ditiru siswa akan terus melekat sehingga akan menjadi karakter dalam dirinya. Mengingat pentingnya keteladanan, maka menurut Zakiah Darajat menyebutkan untuk menjadi seorang guru harus memenuhi syarat: bertakwa kepada Allah, berilmu, sehat jasmani dan rohani, dan berkelakuan baik. Guru harus menjadi tauladan bagi siswa dan lingkungannya (Darajat 2000, 41-44).

Kedua, tugas pendidikan Agama Islam, bukanlah sepenuhnya tanggung jawab sekolah/madrasah dalam hal ini guru Agama Islam, akan tetapi juga menjadi tanggung jawab keluarga dan lingkungan masyarakat. Tidak sedikit anak yang mendapat pendidikan Agama Islam yang baik di sekolah, tetapi karena di rumah atau lingkungannya tidak pernah ditanamkan nilai-nilai religiusitas yang baik, maka anak tersebut menjadi rusak. Oleh karena itu peranan keluarga dan masyarakat terhadap penanaman nilai-nilai pendidikan Agama Islam terhadap anak sangat dibutuhkan.

Ketiga,pentingnya evaluasi, evaluasi bukan hanya dilakukan di sekolah/madrasah secara formal baik formatif maupun sumatif. Lebih dari itu, evaluasi yang dilakukan oleh lingkungan sosial masyarakat sangatlah penting. Jika di sekolah siswa dinilai lebih pada nilai akademis, namun di masyarakat, siswa dinilai akan kesalehan pribadinya yang tercermin dari sikap dan prilakunya (akhlaq).

Abuddin Nata menawarkan solusi untuk mengatasinya. Pertama, dengan merubah orientasi dan fokus pengajaran agama yang semula bersifat subject matter oriented, yakni dari semula yang berpusat pada pemberian pengetahuan agama dalam arti memahami dan menghafal ajaran agama sesuai kurikulum, menjadi pengajaran agama yang berorientasi pada pengamalan dan pembentuk sikap keagamaan melalui pembiasaan hidup sesuai dengan agama. Kedua, dengan cara menambah jam pelajaran agama yang diberikan di luar jam pelajaran yang tetapkan dalam kurikulum. Penambahannya itu dengan bentuk ekstrakurikuler dengan kegiatan shalat berjama'ah, pendalaman agama melalui pesantren kilat, qiyamul lail, berpuasa 
sunah, memberikan santunan kepada fakir miskin, kegiatan sosial keagamaan lainnya. Ketiga, dengan cara meningkatkan perhatian, kasih sayang, bimbingan, dan pengawasan yang diberikan oleh kedua orang tua di rumah. Keempat, melaksanakan tradisi keIslaman yang didasarkan pada al-Qur'an dan as-Sunnah yang disertai dengan pengahayatan akan makna dan pesan moral yang terkandung di dalamnya. Kelima, pembinaan sikap keagamaan tersebut dapat pula dilakukan dengan memanfaatkan berbagai media masa yang tersedia, seperti radio, surat kabar, buku bacaan, televisi dan lain sebagainya (Nata 2003, 23).

\section{Catatan akhir}

Kurikulum PAI merupakan seperangkat rencana kegiatan dan pengaturan mengenai isi dan bahan pelajaran PAI serta cara yang digunakan dan segenap kegiatan yang dilakukan oleh guru agama untuk membantu seorang atau sekelompok siswa dalam memahami, menghayati, dan mengamalkan ajaran Islam atau menumbuhkembangkan nilai-nilai Islam. Termasuk juga didalamnya segenap fenomena atau peristiwa perjumpaan antara dua orang atau lebih yang berdampak pada tertanamnya ajaran Islam dan.atau tumbuh kembangnya nilai-nilai Islam pada salah satu atau beberapa pihak. Pada yang terakhir ini biasanya terwujud dalam bentuk penciptaan suasana religius di sekolah.

Pendidikan Agama Islam di sekolah pada dasarnya lebih diorientasikan pada tataran moral action yakni agar peserta didik tidak hanya berhenti pada tataran kompeten tetapi memiliki kemauan dan kebiasaan dalam mewujudkan ajaran dan nilai-nilai agama tersebut dalam kehidupan sehari-hari.

Berbagai kritik atas atas kelemahan dari pelaksanaan pendidikan agama lebih banyak bermuara pada aspek metodologi Pembelajaran PAI dan orientasinya yang lebih bersifat normatif, teoritis dan kognitif, serta kurang mempunyai relevansi terhadapperubahan sosial yang terjadi di masyarakat atau kurang ilustrasi konteks sosial budaya dan bersifat statis tidak kontekstual serta lepas dari sejarah, 
sehingga peserta didik kurang menghayati nilai-nilai agama sebagai nilai yang hidup dalam keseharian dan lain-lain.

\section{Daftar Pustaka}

Ahmad, M. dkk. 1998. Pengembangan Kurikulum, Bandung: Pustaka Setia.

Amri, Sofan dan Iif Khoiru Ahmadi. 2010. Konstruksi Pengembangan Pembelajaran; Pengarubnya Terbadap Mekanisme dan Praktik Kurikulum. Jakarta: Prestasi Pustaka Publisher.

Arifin, Zainal. 2012. Konsep dan Model Pengembangan Kurikulum, Bandung: Remaja Rosdakarya.

Azra, Azyumardi. 2009. Pendidikan Islam di Era Globalisasi: Peluang dan Tantangan dalamMereka Bicara Pendidikan Islam: Sebuah Bunga Rampai. Jakarta: Raja GrafindoPersada.

Darajat, Zakiah. 2000. Ilmu Pendidikan Islam, Jakarta: Bumi Aksara. Departemen Agama RI. 2003. Memahami Paradigma Baru Pendidikan Nasional dalam Undang-Undang Sisdiknas. Depag RI: Dirjen Kelembagaan Agama Islam.

Furchan, Arief dkk. 2005. Pengembangan Kurikiulum Berbasis Kompetensi di Perguruan Tinggi Agama Islam, Yogyakarta: Pustaka Pelajar.

Hamami, Tasman. 2006. Pemikiran Pendidikan Islam, dalam ringkasan Desertasi Program Pasca Sarjana UIN Yogyakarta.

Idi, Abdullah, 2010. Pengembangan Kurikulum: Teori dan Praktik, Yogyakarta: Ar-ruz Media.

Majid, Abdul dkk. 2005. Pendidikan Agama Islam Berbasis Kompetensi, Bandung: Remaja Rosdakarya.

Muhaimin. 2004. Paradigma Pendidikan Islam. Bandung: Remaja Rosdakarya.

Muhaimin. 2009. Rekontruksi Pendidikan Islam. Jakarta: Rajawali Press.

Muhaimin. 2005. Pengembangan Kurikulum Pendidikan Agama Islam; di Sekolah, Madrasah, dan Perguruan Tinggi. Jakarta: Raja Grafindo Persada. 
Muhaimin. 2006. Nuansa Baru Pendidikan Islam. Jakarta: Raja Grafindo.

Mulyasa, E. 2006. Kurikulum Tingkat Satuan Pendidikan. Bandung:. Remaja Rosdakarya.

Munir. 2010.Kurikulum Berbasis Teknologi komunikasi dan Informasi. Bandung: Alfabeta.

Mudzhar, M. Atho. 2010. Pendidikan Agama di sekolah dalam persfektif HAM, dalam mereka bicara pendidikan Islam; Sebuab Bunga Rampai. Jakarta: Rajawali Press.

Mohammad, Omar al-Toumy al-Syaibani. 1979. Falsafah Pendidikan Islam, ter. Hasan langgulung, Jakarta: Bulan Bintang.

Nata, Abuddin. 2003. Manajemen pendidikan: Mengatasi Kelemahan pendidikan Islam di Indonesia. Jakarta: Prenada Kencana.

Ramayulis. 2004. Ilmu Pendidiken Islam. Jakarta: Kalam Mulia.

Sanjaya, Wina. 2008. Kurikulum dan Pembelajaran. Jakarta: Kencana Prenada Media Group.

Sukmadinata, Syaodih Nana. 2000. Pengembangan Kurikulum: Teori dan Praktik. Bandung: Remaja Rosdakarya.

Tafsir, Ahmad. 2013. Penelitian Pada Pendidikan Agama Islam, Studium General, Program Magister PAI UIN Jakarta , 6 November 2013.

UU Sisdiknas No. 20 Tahun 2003 tentang Sisitem Pendidikan Nasional, Bandung: Citra Umbara. 